\title{
Future Directions for Conservation
}

\section{Jozef Keulartz}

\begin{abstract}
The use of target baselines or reference states for conservation and restoration has become increasingly problematic and impractical, due to rapid environmental change, the paradigm shift in ecology from a static to a dynamic view of nature, and growing awareness of the role of cultural traditions in the reconstruction of baselines. The various responses to this crisis of baselines will to a significant extent determine the future direction of nature conservation. Although some hold on to traditional baselines and others try to refine or redefine the reference concept, the debate is currently dominated by two widely diverging reactions to the crisis: while the so-called 'new environmentalists' or 'new conservationists' declare the whole baseline notion obsolete, replacing a backward-looking approach by a forward-looking one, the 're-wilders' push the baseline back to a deeper, more distant past. This article provides a critical assessment of the debate on these conversation options, with a special focus on the differences between Old World and New World perspectives.
\end{abstract}

\section{Keywords}

Conservation baselines; Old World and New World perspectives; novel ecosystems; anthropocene; rewilding

\section{Introduction}


New World and Old World conservationists use different historical baselines or reference states. Ecological restoration in the New World comes down to returning habitats or ecosystems to the way they were when Europeans arrived to settle the area - for North America the year 1492 is a holy baseline, for Australia it is 1770 when Captain Cook first landed there. Ecological restoration in the Old World on the other hand uses the pre-industrial (and not the pre-settlement) landscape of the mid-nineteenth century as baseline and aims to return ecosystems to their condition prior to large-scale modernization (Ladle et al. 2011).

These different baselines correspond to Simon Schama's distinction in Landscape and Memory between two kinds of Arcadia, the primitive and the pastoral. "There have always been two kinds of Arcadia: shaggy and smooth; dark and light; a place of bucolic leisure and a place of primitive panic" (Schama 1995, 517). Whereas primitive Arcadia is inhabited by people who behave like wild animals, pastoral Arcadia is a place from which all dangerous creatures (such as the snake and the lion) have been banned and the ideal animals (such as the cow and the bee) behave like conscientious and industrious citizens. Primitive Arcadians are "hunters and gatherers, warriors and sensualists" (ibid., 527), who seek shelter against the elements in caves or simple huts; pastoral Arcadians, on the other hand, are agriculturists, who have replaced hunting and gathering by farming and herding, and who have exchanged nomadic life for sedentary life.

Both New World and Old World approaches struggle with the problem that target baselines have become increasingly troublesome and impractical (Gillson et al. 2011). On the one hand, the New World idea of a pristine wilderness devoid of human effects has been deflated when it became apparent that many wilderness areas had been profoundly affected by humans before European conquest and settlement. On the other hand, it is clear by now that preserving or recreating typical Old World cultural-historic landscapes is rendered almost impossible by strong anthropogenic drivers such as climate change and habitat fragmentation. 
There have been two widely diverging reactions to this crisis of conservation baselines. One wing of the conservation community has abandoned history altogether, shifting the focus from the past to the future, and from 'restoration ecology' to 'intervention ecology', under the invocation of the emerging Anthropocene, the 'age of man'. The other wing has moved the baseline back to an even deeper, more distant past, adopting what has been termed 'rewilding' or 'resurrection ecology'.

Although rewilding projects on both sides of the Atlantic have much in common, they also differ in some important respects. In the U.S. the late Pleistocene has been adopted as baseline; in Europe it is the mid-Holocene landscape that functions as the main benchmark. In the U.S. the emphasis is on the reintroduction of large predators because of their role in the top-down regulation of ecosystems; in Europe the emphasis is rather on large herbivores and their role in a resource-driven bottom-up approach.

After careful consideration of the various conservation options, the paper will conclude with a plea for a peaceful co-existence of the different approaches, seeing them as complementary rather than as mutually exclusive.

\section{The American baseline crisis - the wilderness myth unmasked}

The contrast between primitive and pastoral Arcadia, between the hunter-gatherer who is supposed to live a hand-to-mouth existence, never staying long enough in any one place to leave lasting human imprints, and the agriculturalist who completely transforms wildland environments, has had a profound impact on the American perception of wilderness as a pristine nature devoid of human effects. This conception, as developed by John Muir, Theodore Roosevelt and Aldo Leopold among others, was at the heart of the creation of a system of National Parks, first in the U.S. and later in Canada, Australia and New Zealand (Callicott \& Nelson 1998). In Europe, the idea of National Parks didn't take root - they were 
only established in some sparsely populated areas in Switzerland and Scandinavia - but lost out to the idea of Nature Monuments with less emphasis on wilderness (see the next section).

As Kat Anderson has noted in her book Tending the Wild about native American knowledge and the management of California's natural resources, early European and American explorers and settlers saw in California's landscape an ever-full horn of plenty that gave the native people no need to be industrious. "In their eyes, native people were merely the reapers of this abundance, not the sowers" (Anderson 2006, 241). But this was a totally false impression, because without an Indian presence, these early explorers and settlers would have encountered less spectacular wildflower displays, fewer large trees, fewer park-like forests, vast grasslands et cetera. Instead of a pristine, virtually uninhabited wilderness, they had arrived in "a carefully tended 'garden' that was the result of thousands of years of selective harvesting, tilling, burning, pruning, sowing, weeding, and transplanting” (ibid., 125/6).

A case in point is one of the greatest icons of American wilderness, Yosemite Valley, established in 1864 as the nation's first natural park. This valley was occupied by the Miwok Indians till 1853, when they were evicted from the valley in the interest of gold miners. Soon after their expulsion it became clear that their land management practices, especially those involving burning, had an important ecological impact. The lack of burning led to the accumulation of detritus and bush which in turn made for much more violent fires and ruined the very scenic views that were meant to be preserved (Olwig 1996).

The idea that man in wilderness areas should act, not as gardeners but as guardians, is becoming more and more obsolete. The magnitude of anthropogenic environmental stress from pollution, habitat fragmentation, biodiversity loss, and, above all, climate change, makes it unavoidable to toss out the 'hands-off' philosophy that has guided stewardship for 50 years. Again Yosemite is a good case in point. As a result of climate change, the Tuolumne Meadows, the largest subalpine meadow in the Sierra Nevada, are being invaded by lodgepole 
pine. Preserving the meadows will require massive and long-term intervention, for instance in the form of regular tree-cutting or irrigation for species intolerant of drier conditions (Solomon 2014).

The cult of pristine wilderness, where indigenous people, under the influence of latenineteenth-century anthropologists, were considered as part of the fauna - 'half man, half beast' -, is still popular among many conservationists and the general public, although it has long been exposed as a cultural construction. But the idea that it is time to move beyond romantic notions of pristine wilderness is increasingly gaining ground. As Emma Marris has argued with great passion, to save nature in a post-wild world, we should replace such antiquated notions with "the concept of a global, half-wild rambunctious garden, tended by us" (Marris, 2011,2). Europeans will find this concept attractive because they have always thought of ecological restoration very much as gardening, or even more as farming.

\section{The European baseline crisis - half-nature under pressure}

European conservationists have always had much less seemingly pristine land to work with than their American, Canadian, and Australian colleagues. ${ }^{1}$ Here, not the primitive Arcadia of hunters and gatherers was considered the ideal baseline, but the pastoral Arcadia of farmers and herders. Marris has noted with some amazement that "Europeans even run their dedicated nature reserves a bit like farms" (ibid., 139). Not, however, like modern farms where intensive and industrial agriculture is predominant, but like traditional farms where small-scale extensive agricultural activities have produced picturesque landscapes with a wide variety of plant and bird species.

\footnotetext{
${ }^{1}$ There are, however, still vast areas of wilderness in the European Artic, including Spitsbergen, the North Pole, Fennoscandia and Northwestern Russia.
} 
An important role in the emergence and development of nature conservation in Europe was played by German Romanticism. The Prussian geographer, naturalist and explorer Alexander von Humboldt, an exponent of a Romantic style within natural inquiry, introduced the notion of 'Monuments of Nature' in 1814 to refer to spectacular trees, rocks, waterfalls, and other impressive landscape elements. Nature Monuments are creations of nature that may at the same time bear witness to cultural history, including agriculture, forestry and landscape gardening. According to the most important nineteenth-century forerunner of the Dutch conservation movement, Frederik van Eeden, Nature Monuments are so attractive because they show a "peaceful fraternization" between nature and humanity (Van Eeden 1862, 213). After the Second World War, Victor Westhoff, a prominent scientific advisor of the Dutch Society for the Protection of Nature Monuments, introduced the term half-nature to characterize the typical pre-industrial agricultural landscapes (Van der Windt 1995, 77-93). The management of these landscapes comes down to a continuation of traditional agricultural techniques such as hunting and fishing, reed and brushwood cultivation, tree planting and felling, mowing and turf cutting, the setting up of duck decoys and the use of water mills

A good example of a pre-industrial agricultural landscape is the inland drift sand landscape of Northwestern Europe. Drift sands represent a typical man-made landscape which emerged with the shift from nomadic farming to sedentary farming and the introduction in the twelfth century of the so-called 'plaggen' agricultural system. Forests were cut to create heath lands to be grazed by sheep during the day. Their manure was collected in deep litter stables (the 'potstal') where the animals spent the night. Heather sods (the 'plaggen') were cut and used as bedding material in the deep litter stables where it was soaked by the manure. The mixture of manure and sods was used to fertilize the arable fields where rye was grown, the main staple food in those days. This medieval system was a vulnerable system - due to 
intensive sheep grazing and sod cutting much of the heather disappeared and the bare soil became exposed to wind erosion which initiated sand drifting.

The territorial expansion of the inland drift sand landscape reached its peak in the nineteenth century. But with the introduction of artificial fertilizers and cheap wool from Australia, this landscape was doomed to gradually disappear. Because the use of sheep and sheep-manure was no longer required, extensive heath lands became superfluous; they were reforested or prepared and used for raising crops.

Currently, inland drifting sands are a typically Dutch phenomenon - more than $90 \%$ of Europe's drifting sands, also called 'Atlantic deserts', are found in the Netherlands. Whereas there were still some 80,000 ha of drifting sands in the Netherlands around the middle of the nineteenth century, today only 1,500 ha ( 2 percent) remain. It is increasingly realized that these small remaining areas represent a unique ecosystem characterized by a special floral and faunal composition adapted to extreme environmental conditions.

Like Yosemite's subalpine meadows, the preservation of these drifting sands is under increasing pressure. Climate change has a disruptive impact on plant and animal life. Entire populations are being confronted with the alternative to move outside their historic ranges or to go extinct. This makes it difficult, if not impossible to guarantee the survival of specific target species in specific places. Moreover, the increased nitrogen deposition, caused by car traffic and fertilizer application, leads to acidification and eutrophication of terrestrial and aquatic ecosystems, and causes open sand areas to become overgrown at an astonishing rate of three hectares per year, driving back some plants and animals into ever smaller areas.

It is evident that historical baselines or reference states are always somewhat arbitrary because of the role that cultural traditions play in their reconstruction. What is more, historical baselines are increasingly being dismissed as irrelevant as strong anthropogenic drivers such 
as climate change, nitrogen deposition, and habitat fragmentation make it difficult, if not impossible, to preserve or recreate historical ecosystems. There are two widely diverging reactions to this situation: whereas one wing of the restoration movement has abandoned history entirely, shifting the focus from the past to the future, another wing has moved the baseline back to an even deeper, more distant past (Alagona et al. 2012). ${ }^{2}$

\section{From the past to the future}

A growing number of members of the conservation community feel that we have entered an era characterized more and more by so-called 'novel ecosystems' (Hobbs et al. 2013). Novel or non-analog ecosystems may contain new, non-historical combinations of species that arise not only through the impact of the deliberate and inadvertent introduction of species from other regions as a consequence of globalization and the increase of trade and tourism but also through land-cover change, pollution, and especially through rapid climate change. Accepting the fact of novel ecosystems means that we must be ready to incorporate many alien species into management plans, rather than eradicating or drastically reducing them (Davis et al. 2011).

It is no coincidence that the concept of novel ecosystems has originated in the New World, because for Europeans novel ecosystems are anything but new. To quote Emma Marris once again: “In places like Europe, I don’t think people care as much about novel

\footnotetext{
${ }^{2}$ Yet another reaction involves a redefinition or refinement of the baseline concept that attempts to factor in the dynamic nature of ecosystems. For instance, Balaguer et al. (2014) have argued that, because it is impossible to identify a single historical reference for dynamic ecosystems, we should develop a 'multiple sequential reference model', selected from an historical series of shifting ecosystem configurations over the past centuries or millennia (see also Davies et al. 2010).
} 
ecosystems, because they don't have the same obsession with pristineness and purity that the Americo-Australian-Pacific Island group does" 3

In fact, the conceptual framework, developed in the edited volume Novel Ecosystems, distinguishes three types of ecosystem: historical systems, which have remained within their historical range of variability; hybrid systems, which are composed of new species combinations and/or abiotic conditions, but can be returned to their historical states; and novel systems, which are irreversibly changed (Hallett et al. 2013). Restoration ecologists mostly work in the area of hybrid ecosystems, trying to restore them to historical ones. But more attention should be paid to novel ecosystems. It is estimated (by Perring \& Ellis 2013) that already about 35 percent of the world's ice-free land is currently covered by novel ecosystems, and, in light of the ongoing human impact on the environment, they are expected to become ubiquitous.

To recognize that some ecosystems are transformed irreversibly and that invasive species will persist in some cases "may seem to some to be a defeatist approach" (Hobbs et al. 2006, 5). On the other hand, "valuing the past when the past is not an accurate indicator for the future may fulfill a nostalgic need but may ultimately be counterproductive in terms of achieving realistic and lasting restoration outcomes" (Harris et al. 2006, 175). In a world that is in ever-greater flux, restoration to a historic standard is becoming more and more anachronistic. Hence the suggestion that we should drop the term 'restoration ecology' with its historical focus, and replace it by the term 'intervention ecology'. This substitution of restoration by intervention signifies a shift from a 'historic' to a 'futuristic' approach to ecosystem management (Choi 2004; Choi et al. 2008). Rather than looking nostalgically to a past that is impossible to restore, "we should intervene with an eye to the future and toward

\footnotetext{
${ }^{3}$ Quote from interview in Leaf Litter Newsletter, 2011, Vol. IX, Edition 4, http://www.biohabitats.com/newsletters/novel-ecosystems-2/
} 
managing for future change" (Hobbs et al. 2011, 444), which basically comes down to maintaining or repairing key ecosystem services. ${ }^{4}$

Novel ecosystems are considered to be a distinctive feature of the emerging Anthropocene era, the age of human dominion of the Earth. Whereas many conservationists bemoan this new world order as ecologically disastrous, an increasing number ask us to celebrate 'the age of man'; they not only promote acceptance of, but also, and above all, admiration for human's newly acquired power over the planet. According to these so-called 'new environmentalists' or 'new conservationists', the Anthropocene does not represent the failure of environmentalism, but should rather be seen, more optimistically, as "the stage on which a new, more positive and forward-looking environmentalism can be built" (Marris et al. 2011).

Whether we accept it or not, having made the leap to an entirely new level of planetary importance, "we are as gods and might as well get good at it" (Ellis 2011) - in other words: we are now de facto planetary managers, and we should take our responsibility seriously and manage the Earth "with love and intelligence" (Marris et al. 2011).

Anthropocene enthusiasts usually claim that nature is not as fragile as the doom and gloom idiom of destruction, depredation and deterioration of old school conservationists suggests, but is surprisingly resilient and often recovers from even severe perturbations (Kaveira \& Marvier 2012, 965).

More importantly, new environmentalists tend to shift the emphasis from the protection of biodiversity conservation for its own sake to the enhancement of "those natural systems that benefit the widest number of people, especially the poor" (Kaviera et al. 2012). They argue for an approach in which the centrality of humans is recognized and in which the improvement of human well-being through the management of the environment plays a key

\footnotetext{
${ }^{4}$ The growing popularity of the concept of ecosystem services within the conservation community testifies to the emergence of enlightened (or prudential) anthropocentrism, where nature is only allowed that degree of agency which is required to deliver the services that are essential for human well-being (Keulartz 2012).
} 
role (Kaviera \& Marvier 2012, 962/3). Rather than assemblages of species, new environmentalists view nature as a bundle of ecosystem services. Promoting and maintaining these services, should be conservation's primary goal, not preventing anthropogenic extinction. "Some human-caused extinctions are inevitable, and we must be realistic about what we can and cannot accomplish. We must be sure to first conserve ecosystems in places where biodiversity delivers services to people in need" (Kaveira \& Marvier 2007, 56).

Not surprisingly, therefore, new conservationists distinguish themselves from old school conservationists by their willingness to work with corporations. "A small number of global corporations have a huge impact on land conversion, mining, energy extraction, and consumer choices. In essence, corporations are the 'keystone species' of global ecosystems" (Kaveira \& Marvier 2012, 967). Instead of scolding capitalism, conservationists should partner with these corporations to achieve better results by dovetailing conservations and economic activities more effectively.

The new conservationists claim that novel ecosystems will inevitably become ubiquitous, taking over the entire planet, and that, consequently, conservationists who cling to historical fidelity will run out of work, except "for only a few boutique restorations jobs" (Marris et al. 2013, 347). Some are even somewhat hesitant to use the concept of novel ecosystems because this would imply the existence of its opposite, and reinforce the notion of some pristine alternative to novel ecosystems. "If there is a 'novel' ecosystem, then there must be an 'old' or 'normal' or 'unchanged' ecosystem out there somewhere, right?" (ibid., $348)$.

It goes without saying that many conservationists are less than amused by this sweeping claim. Some of the most prominent academics and activists from North and South America, Europe, and Australia have recently joined forces in a volume entitled Keeping the Wild; Against the Domestication of Earth. They strongly reject the recent focus on the age of 
man and on human exceptionalism as the latest embodiment of human hubris (Hettinger 2014, 179; cf. Noss et al. 2013, 242). They also strongly reject the assumption that the protection and development of ecosystem services and goods might be the best alternative for the "nostalgic recompositions of the past" (Choi 2007, 352). ${ }^{5}$ The authors of Keeping the Wild offer bold advocacy for free nature in all its diversity, which brings us to the other response to the baseline problem and the growing incapacity to restore historical ecosystems.

Rewilding points in a direction that is diametrically opposed to the one taken by the supporters of a futuristic, forward-looking approach to conservation. Far from abandoning history altogether and dismissing the past as an inaccurate indicator for the future, the rewilders try to reach back to a deeper history. Whereas the preoccupation with novel, nonanalog ecosystems is mainly limited to North America and other parts of the New World, there clearly is growing momentum for rewilding on both sides of the Atlantic.

\section{Resurrection ecology: Pleistocene rewilding}

The word 'rewilding' was coined by David Foreman, a founder of the radical environmental group Earth First!, who also helped to establish both the Wildlands Project (in 1991) and the Rewilding Institute (in 2003). The scientific foundations for the new discipline were laid by another founder of the Wildlands Project (now the Wildlands Network), Michael Soulé and other biologists from the Society for Conservation Biology, of which he was the first President. Together with Reed Noss, Michael Soulé formulated the essence of rewilding in a landmark paper published in 1998, "Rewilding and Biodiversity: Complementary Goals for Continental Conservation." In it, they present three features that characterize contemporary

\footnotetext{
${ }^{5}$ The attractiveness of the concept of ecosystem services is understandable in an era of unprecedented global environmental change, but the concept and the accompanying commodification of the world's 'natural capital' may well have some highly undesirable consequences for both society and nature (Keulartz 2013).
} 
rewilding: large, protected core reserves; connectivity between these reserves; and the presence of top predators and other keystone species, i.e. those species whose impact on their environment is disproportionately large relative to their numerical abundance. In simplified shorthand, these characteristics have usually been referred to as rewilding's three C's: "Cores, Corridors, and Carnivores" (Soulé \& Noss 1998, 22).

Noss and Soulé put most emphasis on large predators because of their role in the topdown regulation of ecosystems. These species occupy the highest trophic level and create impacts that ripple downward along the trophic ladder. They activate trophic cascades that are essential to the preservation of biodiversity and the maintenance of ecosystem integrity (Terborgh et al. 1999; Miller et al. 2001). However, most of these species that play such a crucial and irreplaceable regulatory role were lost after the dispersal of modern humans from Africa and Eurasia. In North America alone more than 50 species of large mammals went extinct after the arrival of the Clovis people some 13,000 years ago, including mammoths, mastodons, horses, giant ground sloths, American camels, lions, and the saber-tooth cats. This catastrophic extirpation - sometimes referred to as the 'Pleistocene overkill' - has started an ecological chain reaction that led to further extinctions and hence to severe ecosystem simplification.

To correct this dramatic megafaunal loss, Josh Donlan and ten other biologists, including Foreman and Soulé, have launched the idea of 'Pleistocene rewilding' (Donlan et al. 2005; 2006). They blame most conservationists and management agencies for suffering from a 'post-Columbian bias', typically turning to 1492 for a restoration baseline. If, however, we accept as benchmark for restoration measures the arrival of people from the Clovis culture we could consider introducing surrogates for some of the North America megafauna that went extinct after the arrival of these people. Paul Martin (2005), the originator of the overkill 
hypothesis, has suggested the term 'resurrection ecology' for the Pleistocene rewilding program. $^{6}$

Pleistocene rewilders recognize that human-induced environmental impacts are now unprecedented and show alarming signs of worsening, with the result that the megafauna that has already disappeared from Europe, Australia and the Americas, could eventually also disappear from Africa and Asia, the only places where megafauna are still relatively intact. Given this risk of further extinction, the rewilders propose using megafauna from these regions, such as camels, cheetahs, elephants and lions, as proxies for extinct American species. Consequently, Pleistocene rewilding is supposed to serve a dual purpose: to restore some of the evolutionary and ecological potential that was lost 13,000 years ago, and to help prevent the extinction of the world's remaining megafauna by creating new, and perhaps better protected, populations in North America.

The Pleistocene rewilders mention not only ecological reasons but also ethical reasons to justify their alternative conservation strategy. Pleistocene rewilding is ethically justified because human beings are to some significant degree implicated in the megafaunal extinctions in North America and elsewhere and thus bear a moral responsibility to vigorously redress this catastrophic losses insofar as possible (Donlan et al. 2006, 666). In addition to the ethical justification for rewilding, Pleistocene rewilders also mention emotional and aesthetic arguments. They point to evidence of our fascination with charismatic megafauna and claim that the establishment of a 'Serengeti of the New World' will create significant economic opportunities for the ecotourism industry. They further argue that wilderness without top carnivores such as cougars, wolves, or black bears can hardly be called 'wild'. "Without these

\footnotetext{
${ }^{6}$ Currently, scientists are trying to bring back extinct animals with the help of synthetic biology. For instance, leading synthetic biologist George Church is working, in partnership with 'Revive and Restore', on a 'deextinction' project of the Long Now Foundation, to bring back to life the iconic extinct passenger pigeon (Ectopistes migratorius). (http://rare.longnow.org/projects.html)
} 
components, nature seems somehow incomplete, truncated, overly tame. Human opportunities to attain humility are reduced" (Soulé \& Noss 1998, 24).

Not unlike the new conservationists, Pleistocene rewilders see their approach as an optimistic alternative to the prevailing 'doom and gloom' message of conservation biology with its paralyzing effect on the general public. It seeks to transform conservation biology from a defensive and reactive discipline into an offensive and proactive discipline, that might galvanize public support for nature conservation. "Moving away from managing extinction and toward actively restoring ecological and evolutionary processes using Pleistocene history as a guide provides an exciting new platform for conservation biology" (Donlan et al. 2006, $664 / 5)$.

As could be expected, Pleistocene rewilding was not only welcomed with enthusiasm but has also met with firm criticism. Many opponents challenge the science behind this conservation strategy (Rubenstein et al. 2006). They reject the possibility of restoring the evolutionary potential of North America's extinct megafauna with the help of African and Asian proxies because of the differences in genetic makeup. They also question the claim that the ecological potential of North America's ecosystems can, at the same time, be restored by using proxy species, because these ecosystems are different from the Pleistocene ecosystems, as well as from the ecosystems that are home to the extant African and Asian megafauna. Taken together, these differences make it probable that the proxies will act like invasive species that could devastate populations of indigenous species and wreak havoc in native environments. ${ }^{7}$ Rubenstein and colleagues in fact fear that the translocation of exotic species to non-native habitats could result in novel ecosystems with unique species compositions and unknown functional features.

\footnotetext{
${ }^{7}$ Because the intended or accidental introduction of invasive species is one of the primary drivers of biodiversity loss, "the rationale and methodology for Pleistocene re-wilding ultimately represents unsound conservation practice" (Huynh 2010, 100).
} 
Apart from ecological concerns, critics also point to the high economic costs of Pleistocene rewilding. The acquisition of land, the translocation and monitoring of animals, and the fencing of large areas will require considerable financial resources. It is feared that, given these high costs, in combination with the comparatively high salaries of North American managers and scientists, attention and funding will be diverted from more traditional conservation strategies in Asia and Africa as well as in North America (Caro 2007). It is also feared that Pleistocene rewilding might negatively affect Africa's ecotourism "if tourists and hunters, unwilling or unable to travel overseas, could view wildlife and hunt mega-fauna in their own North American backyard" (Toledo et al. 2011, 566).

Possible resistance by rural communities is another area of concern. People will respond with fear rather than fascination when they, and their livestock, have to face catastrophic disease transmission and are exposed to dangerous predators. An email that Josh Donlan has received during the height of the media attention for Pleistocene rewilding shows the deep-seated fear and hate of these animals: "Turning loose wild animals in USA anywhere is moronic. You must not have any children or if you do you must think its ok that they will be lion food. You are $\mathrm{f}^{*} \$ \#$ ing moron if you release killers in our homeland. I hope the cattle rancher guys shoot your ass or feed you to those lions if you release those killers into our ecosystem” (Donlan \& Greene 2010, 298).

Finally, the ethical justification for Pleistocene rewilding can also be questioned, because the overkill hypothesis that puts the blame for megafaunal extinctions on humans und thus requires redress is far from uncontroversial (Wolverton 2010). There are now no fewer than three alternative hypotheses, known tongue-in-cheek as overchill, overill, and overgrill. The overchill hypothesis states that climate changes at the end of the Pleistocene epoch has triggered the megafaunal collapse; the overill hypothesis supposes that the megafauna were 
wiped out by some very virulent and very lethal 'hyperdisease'; the overgrill hypothesis claims that a comet impact or airburst over North America did it.

\section{Rewilding goes Dutch}

On the other side of the Atlantic, rewilding has also gained considerable momentum. Martin et al. (2008) mention two developments that have contributed to the rising enthusiasm for rewilding: the fall of the Iron Curtain, which revealed large natural areas in Central and Eastern Europe, and created opportunities to turn them into government-protected areas; and the change in Europe's common agricultural policy, which has led to significant conservation opportunities in depopulated rural areas. ${ }^{8}$

In Europe, rewilding has gone Dutch, to paraphrase a chapter title of Andrew Balmford's 2012 book Wild Hope. Balmford refers to the Oostvaardersplassen, a polder situated 5 meters below sea level and just half an hour from Amsterdam. Reclaimed from the sea in 1968 , this marshy area of 6,000 ha was initially earmarked for industry, but soon evolved into a perfect habitat for plant and bird species that had become very rare in the Netherlands, or had completely disappeared from the country. The site became a nature reserve of international importance, where Frans Vera and his colleagues initiated a management approach of rewilding with large ungulates. The rapid adoption of the ideas behind the Oostvaardersplassen project by agencies from other European countries, especially the UK, gives an indication of the influence that the work of Vera and colleagues has had. These ideas have proved "immensely stimulating to conservation biology throughout northern Europe" (Smout 2010, 112).

\footnotetext{
${ }^{8}$ Another development worth mentioning is the establishment of Natura 2000, which aims at creating a coherent network to protect the most valuable nature areas in the EU. Natura 2000 is, without doubt, one of the most ambitious supranational initiatives for nature conservation worldwide and forms the cornerstone of the EU nature conservation policies.
} 
Although the rewilding projects on both sides of the Atlantic have much in common, they apply different baselines. Whereas Donlan and colleagues moved the baseline back to the pre-human past, Vera and colleagues in Europe stay closer to human history and use a preagrarian baseline. Their benchmark is not the late Pleistocene landscape (of around 13,000 ago) but the mid-Holocene landscape (of about 7,000 ago).

During the last Ice Age, large parts of Europe were covered with a mosaic of grasses, herbs and stunted shrubs. This steppe-tundra environment was home to large cold-adapted herbivores such as reindeer, musk ox, mammoth, woolly rhino, the saiga antelope, the steppe wisent, elk and horses. After the last Ice Age, when temperatures began to rise steeply, some of these large animals were forced to move elsewhere, while others went extinct. "Reindeer and musk ox migrated northeast, to the cooler tundra, while the saiga antelope and the Przewalski horse moved eastwards to the steppes. Mammoths and woolly rhinos shuffled on as well but they eventually died out, never finding a climate as congenial as the steppe-tundra they left" (Vera \& Buissink 2007, 24).

The former steppe-tundra that these great mammals had occupied was colonized by large ungulates who had survived the Ice Age in more southern parts of Europe, like red deer, roe deer, elk, wild boar, wisent, aurochs, and tarpan (the successor of the Przewalski horse). However, not all of the megafauna that had taken refuge in Southern Europe were able to migrate back to the north. The largest animal species such as the European elephant, the rhino and the hippo were hunted to extinction by humans that had colonized the Iberian and Italian peninsulas. The same fate also hit the mammoth and the woolly rhino when these hunters began to migrate north (Goderie et al. 2013, 37).

However, unlike the New World rewilders, European rewilders blame 'pastoral' farmers and herders rather than 'primitive' hunters and gatherers for megafaunal extinctions. The transition from hunters and gatherers to farmers and herdsmen, that started sometime 
between 8,000 and 7,000 years ago, did not allow wildlife populations to recover. Quite the contrary, these populations were forced to retreat to ever more inhospitable places because they were seen as competitors with people's domestic livestock for the best feeding grounds. As early farming cleared the natural vegetation and gradually replaced it with agriculture, many of the large ungulates have been decimated, or, like the aurochs and the tarpan, went extinct altogether.

According to Vera, everywhere agriculture leads to simplification and depletion of natural ecosystems. Agriculture is selection: all over the globe, no less than about 40 species of the estimated total of approximately 50,000 natural occurring species of birds and mammals have been domesticated - that is $0.0008 \%$ ! "During the past thousand of years, an enormous area has been cleared using the plough, the axe and fire for the small number of selected species, at the cost of the space for the wild forms of the selected, domesticated species, as well as of the species that were not selected and not domesticated" (Vera 2000, 379).

By contrast with their North American counterparts, European rewilders place less emphasis on the introduction of large carnivores and more on the introduction of large herbivores. Apart from red deer, roe deer, wild boar, and wisent, Old World rewilders also use proxies for the aurochs (Bos primigeniuis) and the tarpan (Equus przewalski gmelini). In the Oostvaarderplassen, Vera and colleagues use Heck cattle, that originated in the 1920s and 1930s in an attempt by the brothers Lutz and Heinz Heck to breed back domestic cattle to the aurochs that went extinct in 1627 (Lorimer \& Driessen 2013). ${ }^{9}$ They also make use of the konik horse, the closest relative to its wild predecessor, the tarpan, the last of which died in the Moscow Zoo in 1887.

\footnotetext{
${ }^{9}$ Because Heck cattle bear less resemblance to the aurochs than some other modern cattle breeds do, a new backbreeding project, Tauros Project, has formed in the Netherlands.
} 
In 1983, 34 Heck cattle and 20 konik horses were introduced to the Oostvaardersplassen. In 2012, a helicopter count revealed about 350 Heck cattle and 1,150 konik horses alongside 3,400 red deer, that were introduced in 1992. Because of these large numbers of free-roaming ungulates the German magazine Der Spiegel has called the Oostvaardersplassen 'the Serengeti behind the dikes.'

It is clear that Old World rewilders with their preference for the restoration of wild large herbivores and the introduction of naturalistic grazing have adopted a resource-driven bottom-up approach, in which the system is regulated by energy moving upward from lower to higher trophic levels, i.e., from plants to herbivores to carnivores. In a bottom-up approach little ecological importance is accorded to carnivores because they sit atop the food chain. As a consequence of this bottom-up approach, the population size of large herbivores in the Oostvaardersplassen and similar reserves is regulated by limited food availability (in combination with harsh winter conditions). Consequently, it is not allowed in these reserves to prevent starvation, either by proactive culling or by supplementary feeding. Only reactive culling to prevent unnecessary and prolonged suffering of moribund animals is allowed. ${ }^{10}$ This would undermine the internal mechanisms of population regulation that herbivores developed in the millennia they have lived in an environment with periodic food shortages. Red deer, for instance, are able to resort to a strategy of what has been called 'hidden hibernation'; their heart rate goes down to 30 beats per minute, and their energy use decreases to 13 percent of the annual average. Another mechanism concerns the reduced fertility of female animals due to severe weight loss. Red deer in the Oostvaardersplassen produce up to three times fewer calves than in the Veluwe, one of the Netherlands' largest nature reserves, where they are subject to proactive culling.

\footnotetext{
10 This proves to be an important obstacle for the adoption of naturalistic grazing methods in the UK, where animal welfare legislation would at present prohibit Oostvaardersplassen-type food limitation of cattle and horses (Hodder \& Bullock 2010, 227).
} 


\section{Figure 1}

By stressing the key ecological importance of large herbivores for biodiversity conservation, Vera and his colleagues have challenged the widely-held belief that the lowlands of Central and Western Europe at the end of the Pleistocene would have been covered by closed-canopy forest. According to the prevailing succession theories, the original fauna of wild ungulates did not have any influence on the primeval forest structure and dynamics, but were supposed to follow the developments in the vegetation. Under natural conditions, all known wild ungulates were supposed to live at very low densities, such as $0.5-3$ red deer per 100 ha or 4-5 roe deer per 100 ha (Vera 2009, 300). As an alternative to this high-forest hypothesis, Vera proposed his so-called 'wood-pasture' hypothesis. Based on ecological, palynological, etymological and historical arguments, he claimed that the mid-Holocene landscape of the European lowlands was an open park-like landscape, in which the indigenous fauna of large herbivores played an essential role in the cyclical turnover of vegetation types and the development of a shifting mosaic of open grassland, scrub and woodland groves. Vera's wood-pasture hypothesis, however, is at the heart of a heated debate between ecologists and archeologists that is far from settled. ${ }^{11}$

Apart from this scientific controversy there is also a social conflict that breaks out repeatedly. The main bone of contention are not 'dangerous' animals, as in the case of Pleistocene rewilding, but 'pitiful' animals. The process know as 'de-domestication', whereby the animals have to learn to fend for themselves is the most controversial because it entails minimizing supplementary feeding and veterinary assistance. Due to population growth and the resulting increase in grazing intensity there is always the risk of food shortage. The

\footnotetext{
11 According to Vera, the defenders of the high-forest hypothesis have fallen victim to the so-called 'shifting baseline syndrome'. Fisheries biologist Daniel Pauly introduced this term to signal a disturbing trend in resource management where each generation of scientists "accepts as a baseline the stock size and species composition that occurred at the beginning of their careers, and uses this baseline to evaluate changes... The result obviously is a gradual accommodation of the creeping disappearance of resource species" (Pauly 1995). Because the supporters of the high-forest hypothesis don't acknowledge the size and significance of large herbivores in the past, they consider pastures “to be artificial products, 'stolen' from the forest" (Vera 2009, 29).
} 
condition of the animals declines in the winter and the early spring, which results in growing numbers of starving animals. The national forest service does intervene for the sake of animal welfare on the basis of the so-called 'predator model.' If an animal's behavior reveals its death is impending it is shot (reactive culling). Time and again this situation provokes fierce protests stretching from local people to the national parliament (Klaver et al. 2002; Keulartz 2009).

Public and political commotion escalated in the winter of 2004/2005. In that period $14 \%$ of the konik horses died, $22 \%$ of the red deer, and $34 \%$ of Heck cattle. The minister of Agriculture, Nature and Fisheries asked two national councils for advice, the Council for the Rural Area, and the Council for Animal Affairs.

The Council for the Rural Area advised the minister to accept periodical reductions in animal welfare as a consequence of ecological management. This kind of management should be optimized by improving the so-called predator model and by expanding the area available for the animals. The Council also advised the minister to improve public communication of this kind of ecological management.

The Council for Animal Affairs fiercely opposed these conclusions. It was of the opinion that the carrying capacity of the area had been substantially exceeded and that management had failed. The Council's chairman even compared the situation to that of a concentration camp. According to the Council this kind of 'animal experiments' should be abandoned. The total population should be reduced to 1500 animals by shooting animals in small numbers all year round (proactive culling), and selling the meat for consumption. It would possibly be best, however, to remover the cattle and horses and only use deer to graze the area. Also, contraception should be considered.

This discord is typical for the conflict between animal ethicists and animal protectionists on the one hand and nature and wildlife conservationists on the other. Animal 
protectionists generally prioritize the welfare and rights of individual animals, and tend to downplay the importance of species preservation and the prevention of biodiversity loss. ${ }^{12}$ Wildlife conservationists oppose this individualistic approach of animal protectionists and embrace a more holistic view in which individual organisms are perceived as parts of a greater whole such as populations, species or ecosystems. The Oostvaardersplassen provides a striking example of the often very virulent character of this conflict between individualistic animal-centered ethicists and holistic species-centered ethicists.

\section{Discussion}

It is clear from this overview that there is a growing number of uncertainties with respect to conservation policies and practices on both sides of the Atlantic. Should we go back to prehuman, pre-settlement, pre-agrarian or pre-industrial times? Or should we give up the notion of 'restoration' altogether and instead focus on 'intervention' for the sake of securing the provision of ecosystem goods and services? Or should we resort to the 'resurrection' of extinct wildlife, through the use of proxies from Asia and Africa (as in the case of rewilding in the U.S.) or through back breeding (as in the case of rewilding in Europe)? I think that there are many good reasons for the view that we do not need to opt for only one of these different alternatives, but that we should feel free to move in multiple directions, depending on the (a)biotic conditions and the socio-cultural context of an area. I will briefly mention three of them.

First, there is no real contradiction or conflict between the top-down regulation through large carnivores in the U.S. and the bottom-up regulation through large herbivores in Europe. "Reducing trophic interactions to a dichotomous rubric of either top-down or bottom-

\footnotetext{
${ }^{12}$ They tend to endorse Dale Jamieson's view that the notion of a species is an abstraction and that only individual creatures have welfares (Jamieson 1995).
} 
$u p$ is counterproductive. It is clear that forces flow in both directions simultaneously and interact while doing so" (Miller et al. 2001, 203). For example, it is evident that large carnivores play a role in naturalistic grazing, not so much by regulating the numbers of large herbivores, but rather by shaping their foraging patterns, which have a major impact on an area's vegetational development. After reintroduction of large predators (and the 'ecology of fear'), these patterns reflect their need to balance demands for food and safety by fear of predation. This usually has a beneficial impact on the biodiversity of particular areas. Because of the complementary character of both rewilding approaches, it is high time for a transatlantic dialogue, in which experiences and insights with respect to conservation issues can be exchanged (Drenthen \& Keulartz 2014).

Secondly, the positions of the rewilders and the new conservationists are less antithetical than the heated debate between them seems to suggest. On the one hand, as already indicated, some critiques fear that the attempt to restore the evolutionary and ecological potential of North America's extinct megafauna with the help of African and Asian proxies will not result in 'historic' wild ecosystems of the Pleistocene but 'could instead result in 're-wilded' novel, or emerging, ecosystems with unique species compositions and new or altered levels of ecosystem functioning" (Rubenstein et al. 2006, 233). On the other hand, novel systems are supposed to "manifest key characteristics of wildness including ongoing change, uninhibited growth and free-flowing evolutionary processes. Over time, novel ecosystems may become the new normal, and as such become representative of new values of wildness" (Light et al. 2013, 259). Historic ecosystems that have lost their wildness because they require ever more intensive management, are now being replaced by novel ecosystems as the new centers of undirected evolution and wildness (Marris et al. 2013, $348)^{13}$

\footnotetext{
${ }^{13}$ In an interview from 2014 with the American Society of Landscape Architects, Emma Marris even proposes to use the notion of 'the new wild' for novel ecosystems (http://www.asla.org/ContentDetail.aspx?id=34133).
} 
Thirdly, it should be borne in mind that the whole discussion of the novel ecosystem concept is fraught with ambivalence. At one moment, some authors claim that everything is a novel ecosystem, that conservationists should look only forward and shake off the yoke of history entirely (see Marris et al. 2013), at another moment they claim to champion novel ecosystems "not above or instead of more historical ecosystems but in addition to" (Marris 2014). This last claim seems to be in line with the editors of Novel Ecosystems, who caution that the book is not a polemic against traditional conservation approaches aiming to restore historical ecosystem structures and functions, and that "it is not an argument that novelty per se is a good thing and should be encouraged" (Hobbs et al. 2013, 3). As we have seen previously, the conceptual framework, developed in the book, distinguishes historical ecosystems, which have had no change; hybrid ecosystems, where the changes are reversible; and novel ecosystems, where they are irreversible. We should not abandon but continue and even accelerate our efforts to conserve historical ecosystems and to restore hybrid ecosystems, even if this will require large investments, or so the message goes.

In short, there are enough good reasons why we should not try to narrow down our conservation options to just one approach, be it the restoration of historic landscapes, the resurrection of vanished wildlife, or the intervention in novel ecosystems. Instead, we should broaden our scope of options and aim at a peaceful co-existence of the different approaches, seeing them as complementary rather than as mutually exclusive.

Proponents of novel ecosystems should distance themselves more clearly and unequivocally from any claim about the omnipresent and entirely beneficial nature of these systems. Rewilders, on the other hand, should show more pragmatism and recognize the de facto existence of novel ecosystems that are impossible to return to some former state. Rewilders also have to ask themselves whether the concept of rewilding reinforces the line 
between humans and nature, rather than blurring it, and, therefore, represents a serious challenge for traditional cultural-historical ecosystems.

\section{Ackowledgements}

I would like to thank Philip Cafaro and two anonymous reviewers for their valuable comments that helped to improve the text. 


\section{References}

Alagona, P.S., J. Sandlos \& Y.F. Wiersma. 2012. 'Past Imperfect: Using Historical Ecology and Baseline Data for Conservation and Restoration Projects in North America'. Environmental Philosophy 9 (1), 49-70. Anderson, M.K. 2006. Tending the Wild. Native American Knowledge and the Management of California's Natural Resources. Berkeley: University of California Press.

Balaguer, L., A. Escudero, J.F. Martín-Duque, I. Mola \& J. Aronson. 2014. 'The historical reference in restoration ecology: Re-defining a cornerstone concept'. Biological Conservation 176: 12-20.

Balmford, A. 2012. Wild Hope. On the Front Lines of Conservation Success. Chicago and London: The University of Chicago Press.

Callicott, B. \& M. Nelson (eds.). 1998. The Great New Wilderness Debate. Athens and London: The University of Georgia Press.

Caro, T. 2007. 'The Pleistocene re-wilding gambit.' Trends in Ecology and Evolution 22 (6), 281-283.

Choi, Y.D. 2004. 'Theories for Ecological Restoration in Changing Environment: Toward "Futuristic" Restoration'. Ecological Research 19: 75-81.

Choi, Y.D. 2007. 'Restoration Ecology to the Future: A Call for New Paradigm'. Restoration Ecology 15 (2), $351-353$.

Choi, Y.D., V.M. Temperton, E.B. Allen, A.P. Grootjans, M. Halassy, R.J. Hobbs, M.A. Naeth \& K. Torok. 2008. 'Ecological Restoration for Future Sustainability in a Changing Environment'. Ecoscience 15 (1): 53-64. Davies, A.L. \& M.J. Bunting. 2010. ‘Applications of Palaeoecology in Conservation'. The Open Ecology Journal, 2010 (3), 54-67.

Davis, M., R. Hobbs, A. Lugo, J. Ewel, G. Vermeij, J. Brown, M. Rosenzweig, M. Gardener, S. Carroll et al. 2011. 'Don't Judge Species on their Origins'. Nature 474: 153-154.

Donlan, J. \& P.S. Martin. 2003. 'Role of ecological history in invasive species management and conservation'. Conservation Biology 18, 267-269.

Donlan, J. et al. 2005. 'Re-wilding North America'. Nature 436, 913-914.

Donlan, J. et al. 2006. 'Pleistocene rewilding: An optimistic agenda for twenty-first century conservation'. The American Naturalist 168, 160-183.

Donlan, J. \& H. Greene. 2010. 'NLIMBY. No Lions in My Backyard'. In: M. Hall (ed.), Restoration and History. The Search for a Usable Environmental Past (pp. 293-305). New York/London: Routledge. 
Drenthen, M., \& J. Keulartz (eds.). 2014. Old World and New World Perspectives in Environmental Philosophy. London: Springer.

Ellis, E. 2011. 'Neither good nor bad.' New York Times, 23 May 2011.

Foreman, D. 2004. Rewilding North America. A Vision for Conservation in the $21^{\text {st }}$ Century. Washington: Island Press.

Gillson, L., R.J. Ladle, \& M.B. Araújo. 2011. 'Baselines, Patterns and Process'. In R.J. Ladle \& R.J. Whittaker (eds.) Conservation Biogeography (pp. 31-44). Wiley-Blackwell.

Goderie, R., W. Helmer, H. Kerkdijk-Otten \& S. Widstrand. 2013. The Aurochs. Born to be wild. The Comeback of a European Icon. Zutphen, Netherlands: Roodbont Publishers.

Hallett, L., R.J. Standish, K.B. Hulvey, M.R. Gardener, K.N. Suding, B.M. Starzomski, S.D. Murphy \& J.A Harris. 2013. 'Towards a conceptual framework for novel ecosystems'. In: R.J. Hobbs et al. (eds.). Novel Ecosystems (pp. 16-28).

Harris, J., R.J. Hobbs, E. Higgs \& J. Aronson. 2006. 'Ecological Restoration and Global Climate Change'. Restoration Ecology 14 (2): 170-176.

Hettinger, N. 2014. 'Valuing Naturalness in the "Anthropocene”: Now More than Ever'. In G. Wuerthner, E. Crist \& T. Butler (eds.). Keeping the Wild. Against the Domestication of Earth (pp. 174 -187). Washington, DC: Island Press.

Hobbs, R., S. Arico, J. Aronson, J. Baron, P. Bridgewater, et al. 2006. 'Novel Ecosystems: Theoretical and Management Aspects of the New Ecological World Order'. Global Ecology and Biogeography 15 (1): 1-7. Hobbs, R., L. Hallett,, P. Ehrlich \& H. Mooney. 2011. 'Intervention Ecology: Applying Ecological Science in the Twenty-first Century'. BioScience 61(6), 442-450.

Hobbs, R., E. Higgs \& C. Hall (eds.). 2013. Novel Ecosystems. Intervening in the New Ecological Order. Oxford, UK: Wiley-Blackwell.

Hodder, K. \& J. Bullock. 2010. 'Nature without Nurture?.' In: M. Hall (ed.), Restoration and History. The Search for a Usable Environmental Past (pp. 223-235). New York/London: Routledge.

Huynh, H. 2010. 'Pleistocene re-wilding is unsound conservation practice', Bioessays 33, 100-102.

Jamieson, D. 1995. 'Zoos Revisited.' In: B. Norton, M. Hutchins, E.F. Stevens \& T.L. Maple (eds.) Ethics on the Ark (pp. 52-66). Washington: Smithsonian Institution Press.

Kaveira, P. \& M. Marvier. 2007. 'Conservation for the people'. Scientific American 297, 50-57.

Kareiva, P. \& M. Marvier. 2012. 'What is Conservation Science?'. BioScience 62 (11), 962-969. 
Kaviera, P., M. Marvier \& R. Lalasz. 2012. 'Conservation in the Anthropocene. Beyond Solitude and Fragility'. http://thebreakthrough.org/index.php/journal/past-issues/issue-2/conservation-in-the-anthropocene

Keulartz, J. 2009. 'Boundary work in ecological restoration'. Environmental Philosophy 6(1): 35-55.

Keulartz, J. 2012 'The emergence of enlightened anthropocentrism in ecological restoration'. Nature and Culture 7 (1), 48-71.

Keulartz, J. 2013. 'Conservation through commodification'. Ethic, Policy \& Environment, 16 (3), $294-304$.

Klaver, I., J. Keulartz, H. van den Belt \& B. Gremmen. 2002. 'Born to be Wild: A Pluralistic Ethics Concerning Introduced Large Herbivores in the Netherlands'. Environmental Ethics 24 (1): 3-23.

Ladle, R.J., P. Jepson, \& L. Gillson. 2011. 'Social values and conservation biogeography'. In: R.J. Ladle \& R.J. Whittaker (eds.). Conservation Biogeography (pp. 13-30). Oxford, UK: Wiley-Blackwell.

Light, A., A. Thompson \& E. Higgs. 2013. 'valuing novel ecosystems'. In: Hobbs et al. (eds.) Novel Ecosystems (pp. 257-268).

Lorimer, J. and C. Driessen. 2013. 'Bovine biopolitics and the promise of monsters in the rewilding of Heck cattle'. Geoforum 48, 249-259.

Marris, E. 2011. Rambunctious Garden. Saving Nature in a Post-Wild World. NY: Bloomsbury.

Marris, E. 2014. "'New conservation" is an expansion of approaches, not an ethical orientation'. Animal Conservation (doi:10.1111/acv.12129).

Marris, E., P. Kaveira, J. Mascaro \& E. Ellis. 2011. 'Hope in the Age of Man'. The New York Times, December 7,2011

Marris, E., J. Mascaro \& E. Ellis. 2013. 'Perspective: is everything a novel ecosystem? If so, do we need the concept'. In: Hobbs et al. (eds.) Novel Ecosystems (pp. 345-349).

Martin, P. 2005. Twilight of the Mammoths: Ice Age Extinctions and the Rewilding of America. Berkeley:

University of California Press.

Martin, V., C. Kormos, F. Zunino, T. Meyer, U. Doerner \& T. Aykroyd. 2008. 'Wilderness Momentum in Europe'. International Journal of Wilderness 14 (2), 34-43.

Miller, B., B. Dugelby, D. Foreman, C. Marinez del Rio, R. Noss, M. Philips, R. Reading, M. Soulé et al. 2001.

'The Importance of Large Carnivores to Healthy Ecosystems'. Endangered Species UPDATE 18 (5), 202-210.

Noss, R., R. Nash, P. Paquet \& M. Soule. 2013. 'Humanities Domination of Nature is Part of the Problem: A Response to Kaveira and Marvier'. Biosience 63 (4), 241-242. 
Olwig, K. 1996. 'Reinventing Common Nature: Yosemite and Mt. Rushmore'. In: W. Cronon (ed.), Uncommon Ground: Rethinking the Human Place in Nature (pp. 379-408). New York: W.W. Norton.

Pauly, D. 1995. 'Anecdotes and the shifting baseline syndrome of fisheries'. Trends in Ecology \& Environment 10: 430 .

Perring, M. \& E. Ellis. 2013. 'The extent of novel ecosystems: Long in time and broad in space'. In: R. Hobbs et al. (eds.). Novel Ecosystems (pp. 66-80).

Rubenstein, D.R., D.I. Rubenstein, P.W. Sherman \& T.A. Gavin. 2006. 'Pleistocene park: Does re-wilding North America represent sound conservation for the 21 st century?' Biological Conservation 132, 232-238.

Schama, S. 1995. Landscape and Memory. London: HarperCollins Publishers.

Smout, C. 2010. 'Regardening and the Rest'. In: M. Hall (ed.), Restoration and History. The Search for a Usable Environmental Past (pp. 111-124). New York/London: Routledge.

Solomon, C. 2014. 'Rethinking the Wild. The Wilderness Act Is facing a Midlife Crisis'. The New York Times, July 5, 2014.

Soulé, M. \& R. Noss. 1998. 'rewilding and Biodiversity: Complementary Goals for Continental Conservation'. Wild Earth 8 (3), 19-28.

Terborgh J., J. Estes, P. Paquet, K. Rah, D. Boyd-Heger, et al. 1999. 'The Role of Top Carnivores in Regulating Terrestrial Ecosystems'. In: M. Soule \& J. Terborgh (eds.). Continental Convervation: Scientific Foundations of Regional Reserve Networks (pp. 39-64). Washington D.C.: Island Press.

Toledo, D., M. Agudelo \& A. Bentley. 2011. 'The shifting of ecological restoration benchmarks and their social impacts: digging deeper into Pleistocene re-wilding'. Restoration Ecology 19 (5), 564-568.

Van der Windt, H. 1995. En dan: wat is natuur nog in dit land? Amsterdam: Boom.

Van Eeden, F. 1862. 'Het landschap'. Album der Natuur, 207-221.

Vera, F. 2000. Grazing Ecology and Forest History. Wallingford: CABI International.

Vera, F. 2009. 'Large-scale nature development - the Oostvaardersplassen'. British Wildlife 20 (5) (Special supplement), 28-36.

Vera, F. \& F. Buissink. 2007. Wilderness in Europe. Baarn: Tirion Publishers.

Wolverton, S. 2010. 'The North American Pleistocene overkill hypothesis and the re-wilding debate'. Diversity and Distribution 16, 874-876. 


\begin{tabular}{|c|c|}
\hline New World & Old World \\
\hline Pre-settlement & Pre-industrial \\
Pre-human & Pre-agrarian \\
\hline Late Pleistocene & Mid-Holocene \\
\hline Extinction by hunting & Extinction by farming \\
\hline Top-down: carnivores & Bottom-up: herbivores \\
\hline
\end{tabular}

Figure 1 Differences between Old world and New World perspectives on rewilding 